\title{
Performance and egg quality of commercial laying hens fed with various levels of protected sodium butyrate
}

\author{
M.F. Pires ${ }^{1}$, N.S.M. Leandro ${ }^{1}$, D.V. Jacob ${ }^{2}$, F.B. Carvalho ${ }^{2}$, H.F. Oliveira ${ }^{1 \#}$, J.H. Stringhini ${ }^{1}$, \\ S.F. Pires ${ }^{2}$, H.H.C. Mello ${ }^{1}$ \& D.P. Carvalho ${ }^{1}$ \\ ${ }^{1}$ Federal University of Goiás, Department of Animal Science, Goiânia, Goiás, Brazil \\ ${ }^{2}$ Nutriad Animal Nutrition, Campinas, São Paulo, Brazil
}

(Submitted 18 October 2019; Accepted 27 September 2020; Published 28 November 2020)

\begin{abstract}
Copyright resides with the authors in terms of the Creative Commons Attribution 4.0 South African Licence.
See: http://creativecommons.org/licenses/by/4.0/za

Condition of use: The user may copy, distribute, transmit and adapt the work, but must recognise the authors and the South African Journal of Animal Science.
\end{abstract}

\begin{abstract}
Two experiments were conducted to evaluate the effect of including protected sodium butyrate (PSB) in the diets of laying hens of advanced age on productive performance and egg quality. In experiment 1 , a total of 320 Dekalb White 61-week-old laying hens were distributed in a randomized block design to four treatments $(0,105,210$, and $300 \mathrm{~g} / \mathrm{ton}$ of PSB) with eight replicates of 10 birds. The experiment was conducted over 112 days, divided into four periods of 28 days each. Productive performance and egg quality were evaluated. In experiment 2, a total of 58000 Dekalb White 70-week-old laying hens were assigned to diets containing either 0 or $105 \mathrm{~g} /$ ton of PSB with two replicates of 14500 birds. The experiment was conducted on a commercial poultry farm. Egg production and the percentages of broken eggs and dirty eggs were evaluated. The PSB levels did not influence the productive performance of laying hens. A quadratic effect was observed for eggshell thickness, percentage of eggshell and eggshell strength, reaching maxima at 193,136 and $198 \mathrm{~g} /$ ton of PSB, respectively. A quadratic effect on yolk index reached a minimum at 181 $\mathrm{g} / \mathrm{ton}$ of PSB. The percentages of dirty eggs and broken eggs were lower in laying hens fed $105 \mathrm{~g} / \mathrm{ton}$ of PSB. In conclusion, the addition of PSB to the diets of old laying hens improved the eggshell quality and decreased the percentage of broken and dirty eggs.
\end{abstract}

Keywords: egg quality, laying hens, organic acids, performance, protected sodium butyrate
\#Corresponding author: helder@zootecnista.com.br

\section{Introduction}

Physiological and hormonal changes occur in commercial laying hens as they age, reducing their productive performance and egg quality. Altered gene expression of matrix proteins, and compromised immune function in the uterus in the late phase of production, may be conducive to age-related impairments of eggshell ultrastructure and mechanical properties (Feng et al., 2020). Nutritional strategies have been used to improve egg production and eggshell quality during the late laying period, including supplements of organic minerals (Qiu et al., 2020), probiotics (Zhang et al., 2019) and amino acids (Asghar et al., 2015). Among the additives used in poultry feed, sodium butyrate has been highlighted in recent years.

Sodium butyrate is a salt that is derived from butyric acid and can be used as an additive in animal nutrition in its free or its protected form. Free-form butyrate can be absorbed across the cell membranes in the initial portion of the gastrointestinal tract. Protected butyrate can reach the posterior portion of the digestive system, thereby increasing its mode of action (Van Immerseel et al., 2004; Ahsan et al., 2016). Butyrate is a short-chain fatty acid. It has a trophic effect on the structure and development of intestinal mucosa. Because it acts as a readily available source of energy for poultry, it contributes to villi growth and consequently increases the area for nutrient uptake by enterocytes (Bellaver \& Scheuermann, 2004; Sakomura et al., 2014; Chamba et al., 2014).

When used as a supplement, sodium butyrate can reduce pathogenic microbiota in the gut because of its bactericidal and bacteriostatic action (Ahsan et al., 2016). Butyrate influences endogenous avian cells in 
multiple ways: it is an agonist of free-fatty acid receptors, an inhibitor of pro-inflammatory pathways, an epigenetic modulating agent, and an energy source (Moquet et al., 2016).

Responses to butyrate may be location specific, given the diversity of cell types and $\mathrm{pH}$ conditions that are encountered throughout the gastrointestinal tract (Moquet et al., 2016). Therefore, it is important to determine the level and the form of butyrate to include in diets for laying hens. The drop in gastric $\mathrm{pH}$ caused by butyrate increases the retention time in the digestive system and activates pepsinogen, thus improving protein digestion. In addition, the low $\mathrm{pH}$ of the digesta that enters the duodenum stimulates pancreatic and bicarbonate secretion and improves nitrogen retention and nutrient digestibility (Partanen \& Mroz, 1999).

Hens that were supplemented with protected butyric acid had higher calcium concentration in their bones and improved eggshell quality (Sobczak \& Kozlowski, 2016). Thus, butyrate sodium could be an important nutritional additive to improve the egg quality in the late laying period of hens. Therefore, the objective of this study was to evaluate the effects of including protected sodium butyrate in the diets of older laying hens on their productive performance and the shell quality of the eggs they produce.

\section{Materials and Methods}

The research was approved by the Ethics Committee on Animal Use (Protocol no. 74/14). Experiment 1 was conducted in an experimental shed in Goiânia, Goiás, Brazil (latitude 1640'43" S, longitude 4915'14" $\mathrm{W}$ and altitude $749 \mathrm{~m}$ ). Experiment 2 was conducted in a commercial poultry farm in Pindoretama, Ceará, Brazil (latitude $3^{\circ} 59^{\prime} 41.7^{\prime \prime} \mathrm{S}$, longitude $38^{\circ} 20^{\prime} 12.2^{\prime \prime} \mathrm{W}$ and altitude $40 \mathrm{~m}$ ).

In experiment 1, 320 Dekalb White 61-week-old laying hens were distributed in a randomized block design to four treatments with eight replicates of ten birds each. The study was preceded by an adaption period of 21 days to select hens with similar rates of laying (maximum variation of $10 \%$ ). The hens were assigned to blocks based on their bodyweight (light birds weighing $1.494-1.660 \mathrm{~kg}$ and heavy birds weighing $1.660-1.826 \mathrm{~kg}$ ). The treatments consisted of the addition of $0,105,210$, and $300 \mathrm{~g} / \mathrm{ton}$ of PSB to the feed. The commercial additive Adimix Precision (Nutriad, Dendermonde, Belgium) containing $30 \%$ protected sodium butyrate was used as the source. To constitute the treatments $0,350,700$, and $1000 \mathrm{~g} / \mathrm{ton}$ of Adimix Precision were incorporated into the feed.

The laying hens were housed in a conventional laying shed, covered with clay tiles, and screened on the sides. Galvanized metal wire cages were equipped with aluminium trough-type feeders and nipple-type drinkers. The feed was supplied daily at $08 \mathrm{~h} 00$ and 18:00 throughout the experimental period. Drinkers and facilities were cleaned daily. A 16-hour lighting program was adopted using an automatic light timer. The experiment lasted 16 weeks when the birds were from 61 to 76 weeks old. The experimental diets were formulated from a basal diet (Table 1) based on corn and soybean meal (Rostagno et al., 2011). The diets differed only in the level of PSB. The nutritional contents of the basal diet are given in Table 2.

Table 1 Composition of the basal diet that was fed to laying hens between 61 to 76 weeks old

\begin{tabular}{|c|c|}
\hline Ingredient & $\mathrm{g} / \mathrm{kg}$ of feed \\
\hline Corn & 635.7 \\
\hline Soybean meal $45 \%$ crude protein & 235.1 \\
\hline Limestone & 94.2 \\
\hline Dicalcium phosphate & 13.4 \\
\hline Inert & 1.0 \\
\hline Sodium butyrate & 0 \\
\hline Common salt & 4.7 \\
\hline Soybean oil & 12.9 \\
\hline DL-Methionine & 1.3 \\
\hline Mineral supplement ${ }^{1}$ & 1.0 \\
\hline Vitamin/mineral supplement ${ }^{2}$ & 0.5 \\
\hline L-Threonine & 0.1 \\
\hline L-Lysine $\mathrm{HCl}$ & 0.1 \\
\hline
\end{tabular}

${ }^{1}$ Per kg, copper: $18 \mathrm{mg}$, zinc: $120 \mathrm{mg}$, iodine: $2 \mathrm{mg}$, iron: $60 \mathrm{mg}$, manganese: $120 \mathrm{mg}$

${ }^{2}$ Per kg, folic acid: $500 \mathrm{mg}$, ash: $500 \mathrm{~g}$, niacin: $25 \mathrm{~g}$, calcium pantothenate: $10 \mathrm{~g}$, selenium: $330 \mathrm{mg}$, vitamin A: 8600 iu, vitamin $B_{1}: 1500 \mathrm{mg}$, vitamin $B_{12}: 13 \mathrm{mcg}$, vitamin $B_{2}: 4 \mathrm{mg}$, vitamin $B_{6}: 1700 \mathrm{mg}$, vitamin $D_{3}: 2.000$ IU, vitamiin $E$ : $10.000 \mathrm{IU}$, vitamin $\mathrm{H}: 52 \mathrm{mg}$, vitamin $\mathrm{K}: 1.800 \mathrm{mg}$ 
Table 2 Nutrient contents of the basal diet for laying hens between 61 and 76 weeks old

\begin{tabular}{lc}
\hline Nutrient, per kg & Composition \\
\hline Metabolizable energy, kcal & 2800 \\
Crude protein, g & 160.0 \\
Methionine + cystine, g & 6.0 \\
Methionine, $g$ & 3.7 \\
Lysine, g & 7.4 \\
Calcium, g & 40.2 \\
Available phosphorus, g & 3.4 \\
Linoleic acid, g & 20.1 \\
Arginine, g & 9.8 \\
Chlorine, g & 3.2 \\
Potassium, g & 6.1 \\
Phenylalanine, g & 7.4 \\
Isoleucine, g & 6.2 \\
Leucine, $g$ & 13.7 \\
Threonine, g & 0.55 \\
Tryptophan, g & 0.17 \\
\hline
\end{tabular}

Feed intake, egg weight, egg production and egg quality were recorded. At the end of each 28-day period, feed intake was calculated as the difference between feed offered and leftovers to determine the amount of feed consumed/hen/day, in grams. Feed conversion ratio per dozen eggs was expressed as the total feed intake, in kilograms, divided by the dozens of eggs produced ( $\mathrm{kg}$ feed/dozen eggs). The feed conversion per egg mass was obtained by dividing the total feed intake by the egg mass produced, in kilograms ( $\mathrm{kg}$ feed $/ \mathrm{kg}$ eggs). All eggs collected during the last three days of each period were weighed to the nearest $0.01 \mathrm{~g}$. The mean egg weight was multiplied by the total number of eggs produced during the experimental period, thus obtaining the total egg mass. This value was then divided by the total number of hens per replicate for each 28-day period. Egg production was obtained by recording the number of eggs produced daily throughout the experimental period.

Four eggs produced on the last three days of each period, per replicate, were analysed to evaluate egg quality. Specific gravity was measured by immersing eggs produced in the last day of each period in saline solutions of various concentrations (densities ranging from 1.050 to 1.100 at 0.005 intervals). The eggs were classified according to their specific gravity when they floated (Albino et al., 2014).

Eggshells were washed and dried at room temperature for 72 hours, after which they were weighed. Shell thickness was measured to the nearest $0.01 \mathrm{~mm}$ in two points at the middle-transversal area of the shell, from which an average measure expressed in millimetres $(\mathrm{mm})$ was obtained for statistical analysis.

The yolk index was obtained from the relation between its height and diameter. Albumen index was calculated as the ratio of thick albumen to its mean diameter. The Haugh unit was calculated by the equation

$$
\mathrm{HU}=100 \log \left(\mathrm{H}-1.7 \mathrm{~W}^{0.37}+7.57\right),
$$

where: $\mathrm{HU}=$ Haugh unit; $\mathrm{H}=$ dense albumen height $(\mathrm{mm})$; and $\mathrm{W}=$ egg weight $(\mathrm{g})$.

Eggshell strength was determined by the TA-XT texture analyzer (Texture Analyzer TA-XT Plus, Surrey, England), expressed in Newton (N). Percentage of eggshell was obtained from the relation between the mean eggshell weight and mean egg weight, expressed as a percentage. The heights and diameters of yolk and albumen were measured using a micrometer and a digital calliper, respectively.

The data were submitted to a polynomial regression between the levels of inclusion of protected sodium butyrate. The analyses were performed using R Development software (2015) considering $\alpha=0.05$. The statistical model used was:

$$
y i j=m+t i+e i j
$$


where: $y_{i j}=$ an observation in treatment $\mathrm{i}(\mathrm{i}=1,2,3,4)$ and replicate $\mathrm{j}(\mathrm{j}=1,2,3, \ldots, 8)$;

$m=$ the overall mean;

$t_{i}=$ the fixed effect of treatment $\mathrm{i}(\mathrm{i}=1,2,3,4) ;$ and

$e_{i j}=$ random error, mean 0 and variance $\sigma^{2}$.

Experiment 2 was conducted at a commercial farm with 58000 Dekalb White laying hens, housed in four open poultry sheds with galvanized wire cages, automatic feeders, and nipple type drinkers. The experiment started when the laying hens were 70 weeks old, lasted four weeks, and was preceded by an adaptation period of 14 days. Hens were kept under the same conditions of feeding and handling, following the usual routine of the farm where the experiment was carried out.

Hens were housed in four laying sheds of 14500 birds. The two diets, an unsupplemented control and the same ration supplemented with $105 \mathrm{~g} /$ ton of PSB, were randomly assigned to the sheds. Thus, there were a total of four experimental units. The level at which PSB was included in the supplemented diet was the one that produced the best egg quality in Experiment 1. Hens were exposed to 17 hours of light/day (natural + artificial) throughout the experimental period.

Eggs were collected twice a day during the experimental period to calculate egg production (\%) and counted and classified according to farm procedures. Egg production and the number of broken eggs and dirty eggs were recorded with the mean of each trait being calculated at the end of the experiment.

Data collected in experiment 2 were submitted to analysis of variance with significance determined by the F-test. All analyses were performed using R Development software (2015) considering $\alpha=0.05$. The statistical model used was:

$$
y i j=m+t i+e i j
$$

where: $y_{i j}=$ an observation in treatment $\mathrm{i}(\mathrm{i}=1,2)$ and replicate $\mathrm{j}(\mathrm{j}=1,2)$;

$m=$ the overall mean;

$t_{i}=$ the fixed effect of treatment $\mathrm{i}(\mathrm{i}=1,2) ;$ and

$e_{i j}=$ random error, mean 0 and variance $\sigma^{2}$.

\section{Results and Discussion}

The results of the productive performance of laying hens in experiment 1 (61 to 76 weeks old) are shown in Table 3. There were no effects of protected sodium butyrate on the performance of laying hens.

Table 3 Performance of laying hens from 61 to 76 weeks old fed diets with various levels of protected sodium butyrate

\begin{tabular}{|c|c|c|c|c|c|c|c|c|}
\hline \multirow{2}{*}{ Variables } & \multicolumn{4}{|c|}{ Levels of sodium butyrate, g/ton } & \multirow{2}{*}{$\mathrm{CV}, \%$} & \multicolumn{3}{|c|}{ P-value } \\
\hline & 0 & 105 & 210 & 300 & & Treatment & $\mathrm{L}$ & Q \\
\hline Feed intake, g/hen/day & 102 & 102 & 102 & 101 & 2.43 & 0.660 & 0.780 & 0.793 \\
\hline Egg weight, g & 61.3 & 61.8 & 61.9 & 61.3 & 2.67 & 0.847 & 0.828 & 0.992 \\
\hline FCR, kg/dozen eggs & 1.407 & 1.408 & 1.379 & 1.386 & 3.55 & 0.569 & 0.558 & 0.424 \\
\hline $\mathrm{FCR}, \mathrm{kg} / \mathrm{kg}$ eggs & 1.911 & 1.894 & 1.858 & 1.883 & 3.67 & 0.458 & 0.679 & 0.434 \\
\hline Egg mass, kg/period/ hen & 1.500 & 1.500 & 1.530 & 1.500 & 4.25 & 0.680 & 0.623 & 0.434 \\
\hline Egg production, \% & 87.5 & 87.0 & 88.6 & 87.5 & 3.41 & 0.740 & 0.430 & 0.332 \\
\hline
\end{tabular}

L: linear effect, Q: quadratic effect of including protected sodium butyrate in the ration

The effects of including PSB at various levels in the ration fed to laying hens from 61 to 76 weeks old on egg quality traits are shown in Table 4. Specific gravity, eggshell weight, albumen index, and Haugh unit were unaffected by the level at which PSB was included in the ration. However, feeding PSB improved the quality of eggshells that were produced by old laying hens, as shown by the quadratic effects on eggshell thickness, percentage of eggshell and eggshell strength. Further, a quadratic effect on the yolk index was observed, with a minimum in $181 \mathrm{~g} / \mathrm{ton}$ protected sodium butyrate in the feed. The regression equations 
describing the curvilinear responses are given in Table 5. Maxima of the eggshell thickness, percentage of eggshell and eggshell strength responses were estimated to be at 193, 136 and $198 \mathrm{~g} /$ ton of PSB in the feed, respectively. The minimum yolk index was estimated at an inclusion level of $181 \mathrm{~g} / \mathrm{ton}$.

Table 4 Egg quality of laying hens from 61 to 76 weeks old fed diets with various levels of protected sodium butyrate

\begin{tabular}{|c|c|c|c|c|c|c|c|}
\hline \multirow{2}{*}{ Variables } & \multicolumn{4}{|c|}{ Levels of sodium butyrate, $\mathrm{g} /$ ton } & \multirow{2}{*}{$\mathrm{CV}, \%$} & \multicolumn{2}{|c|}{ P-value } \\
\hline & 0 & 105 & 210 & 300 & & $\mathrm{~L}$ & $Q$ \\
\hline Specific gravity, $\mathrm{g} / \mathrm{cm}^{3}$ & 1.087 & 1.089 & 1.088 & 1.088 & 0.15 & 0.483 & 0.169 \\
\hline Shell thickness, $\mathrm{mm}$ & 0.350 & 0.383 & 0.388 & 0.379 & 2.18 & $<0.001$ & $<0.001$ \\
\hline \% Eggshell & 9.19 & 9.51 & 9.31 & 9.12 & 2.09 & 0.002 & $<0.001$ \\
\hline Shell strength, N & 32.02 & 35.61 & 35.31 & 35.23 & 6.20 & 0.029 & 0.049 \\
\hline Shell weight, g & 5.63 & 5.80 & 5.63 & 5.62 & 2.73 & 0.436 & 0.072 \\
\hline Yolk index & 0.41 & 0.41 & 0.39 & 0.4 & 1.62 & $<0.001$ & 0.002 \\
\hline Albumen index & 0.10 & 0.10 & 0.09 & 0.10 & 4.53 & 0.260 & 0.778 \\
\hline Haugh unit & 76.1 & 75.7 & 76.4 & 75.2 & 2.04 & 0.402 & 0.481 \\
\hline
\end{tabular}

L: linear effect, Q: quadratic effect of including protected sodium butyrate in the ration

Table 5 Regression equations describing the significant observed curvilinear responses in egg quality traits for laying hens from 61 to 76 weeks old fed diets with various levels of protected sodium butyrate

\begin{tabular}{lrrr}
\hline Variables, $\mathrm{Y}$ & Regression equation & $\mathrm{R}^{2}, \%$ & \multicolumn{1}{c}{ First derivative } \\
\hline Shell thickness, $\mathrm{mm}$ & $\mathrm{Y}=0.3508+0.0004107 \mathrm{X}-0.000001064 \mathrm{X}^{2}$ & 99 & $\frac{d y}{d x}=0.0004107-0.000002128 \mathrm{X}$ \\
\% Egg shell & $\mathrm{Y}=9.207+0.00371 \mathrm{X}-0.00001365 \mathrm{X}^{2}$ & 88 & $\frac{d y}{d x}=0.00371-0.00002730 \mathrm{X}$ \\
Shell strength, $\mathrm{N}$ & $\mathrm{Y}=32.22+0.03731 \mathrm{X}-0.00009405 \mathrm{X}^{2}$ & 90 & $\begin{array}{r}\frac{d y}{d x}=0.03731-0.0001881 \mathrm{X} \\
\text { Yolk index }\end{array}$ \\
& $\mathrm{Y}=0.4129-0.0001466 \mathrm{X}+0.0000004046 \mathrm{X}^{2}$ & 20 & $\frac{d y}{d x}=-0.0001466+0.0000008092 \mathrm{X}$ \\
\hline
\end{tabular}

X: level of inclusion of protected sodium butyrate in the ration

The results obtained in Experiment 2 are shown in Table 6. The use of protected sodium butyrate did not affect the egg production. However, the numbers of dirty eggs and broken eggs were lower to laying hens fed $105 \mathrm{~g} /$ ton of PSB.

The inclusion of PSB in the diet did not influence the productive performance of commercial laying hens from 61 to 76 weeks old in Experiment 1. Previously, it had been indicated that butyrate supplementation improved productive performance, shell quality and intestinal villi integrity in hens (Herrera et al., 2009), However, there were differing results among studies, and Rahman et al. (2008) did not find significant differences in feed intake, feed conversion and egg weight of laying hens at $67-74$ weeks old supplemented with a commercial additive composed of different free organic acids (including sodium butyrate). 
Table 6 Performance of laying hens in commercial sheds fed with or without protected sodium butyrate from 72 to 76 weeks old

\begin{tabular}{|c|c|c|c|c|}
\hline \multirow{2}{*}{ Variables, \% } & \multicolumn{2}{|c|}{ Levels of sodium butyrate, $\mathrm{g} / \mathrm{ton}$} & \multirow{2}{*}{$P$-value } & \multirow{2}{*}{$\mathrm{CV}, \%$} \\
\hline & 0 & 105 & & \\
\hline Egg production & 87.76 & 87.71 & 0.829 & 1.02 \\
\hline Dirty eggs & 3.11 & 1.32 & $<0.001$ & 39.97 \\
\hline Broken eggs & 1.56 & 1.17 & 0.004 & 30.43 \\
\hline
\end{tabular}

In Experiment 1, it was found that eggshell quality was improved in laying hens fed diets containing PSB. The eggshell thickness, percentage of eggshell and eggshell strength were maximized at 193, 136 and $198 \mathrm{~g} /$ ton of PSB in diet, respectively. Therefore, levels above these decreased the eggshell quality. The variables related to eggshell quality are associated with calcium deposition in the shell. As hens grow older, egg production gradually decreases, whereas fat deposition in the reproductive system and egg size increase (Albinoet al., 2014). However, the increase in egg size was accompanied by a reduction in eggshell thickness and strength since the amount of calcium deposited in the eggshell remained constant (Carvalho \& Fernandes, 2013). In addition to the increase in egg size, the cells in the intestinal mucosa weaken and there is a decrease in villi height of duodenum as hens grow older. These effects result in higher energy expenditure to repair the mucosa and impaired absorption of nutrients needed for eggshell formation (Belyavin et al., 1987). Since butyrate is an important substrate for energy metabolism in the gut, it is possible that dietary inclusion of sodium butyrate provides a readily available source of energy to enterocytes.

The effects of butyrate are seemingly more evident on the improved intestinal structure and modulation of the microbial community (Wo et al., 2018), immune response (Zhang et al., 2011), nutrient retention (Khong et al., 2014), ammonia production (Wang et al., 2016), and eggshell quality (Sobczak \& Kozlowski, 2016) than in productive performance. Van Immerseel et al. (2004) added that PSB had a trophic effect on the structure and development of intestinal mucosa, acting as a readily available source of energy for cells of the intestinal epithelium in poultry. It boosted the growth of villi and crypt depth and consequently increased the area for nutrient absorption.

The improvement in eggshell quality as observed in experiment 1 might thus be explained by the additive providing energy to the intestinal mucosa and facilitating an increase in the metabolizability and retention of nutrients with downstream effects resulting in increased calcium deposition in the eggshell and proteins in the eggshell membrane. Sengor et al. (2007) found better eggshell quality with the use of a commercial additive containing sodium butyrate in 75- to 81 -week-old hens relative to those that were fed a control diet. Rahman et al. (2008) also reported improved eggshell quality of for laying hens of 67 to 74 weeks old that were fed a commercial additive containing free sodium butyrate, relative to those fed the control diet. Soltan (2008) observed increased thickness of the eggshells from lightweight laying hens fed the same commercial additive containing free sodium butyrate. They concluded that the best dietary level was $1.5 \mathrm{~g} / \mathrm{kg}$, a level that is substantially higher than any level used in the present research.

The albumen and Haugh unit index were not influenced by the treatments. However, the yolk index decreased to the level of $181 \mathrm{~g} / \mathrm{ton}$ of PSB in the feed. The mechanism of action of butyrate in decreasing the yolk index is not known. When evaluating the internal quality of eggs of commercial laying hens with 74 weeks old fed a commercial additive composed of free organic acids, Rahman et al. (2008) did not find differences in yolk index and Haugh unit, but observed an improvement in the albumen index when 1.0 and $1.5 \mathrm{~g} / \mathrm{kg}$ of additive were fed.

Relative to Experiment 2, there was no significant difference in egg production, but there was a decrease in the percentage of dirty eggs and broken eggs in commercial laying hens fed $105 \mathrm{~g} /$ ton of PSB. This effect may be related to improvement in intestinal quality with the use of PSB in the diet, providing better nutrient utilization. Another factor that could have contributed to ameliorating the percentage of dirty and broken eggs was microbiota modulation. Wo et al. (2018) concluded that sodium butyrate supplementation in broiler diets improved the intestinal development, morphological structure, and biological functions of broilers through modulation of the microbial community, which seemed to be optimized for gut health.

\section{Conclusions}


The inclusion of PSB in the diet of laying hens did not appear to affect the productive performance of birds. However, it increased the eggshell quality of old laying hens by improving shell thickness, strength and the percentage of egg weight that was attributable to the shell. On a commercial scale, supplemental PSB also decreases the percentages of broken and dirty eggs.

\section{Acknowledgements}

This study was financed in part by the Coordenação de Aperfeiçoamento de Pessoal de Nível Superior, Brasil (CAPES). Finance Code 001.

\section{Authors' Contributions}

MFP, NSML and DVJ conceived and designed the experiments. MFP, SFP and DPC performed the experiments. MFP and NSML analysed the data. NSML, DVJ, FBC and JHS contributed reagents, materials, and analytical tools. MFP, NSML, HFO and HHCM wrote the paper. HFO and HHCM edited the manuscript.

\section{Conflict of Interest Declaration}

The authors have no conflict of interest to declare.

\section{References}

Ahsan, U., Cengiz, Ö., Raza, I., Kuter, E., Chacher, M. F. A., Iqbal, Z., Umar, S.\& Çakir, S., 2016. Sodium butyrate in chicken nutrition: The dynamics of performance, gut microbiota, gut morphology, and immunity. World's Poult. Sci. J. 72, 265-276. https://doi.org/10.1017/s0043933916000210

Albino, L.F.T., Carvalho, B.R., Maia, R.C. \& Barros, V.R.S.M., 2014. Formação e qualidade dos ovos. Editora Aprenda Fácil, Minas Gerais, Brazil.

Asghar, S.A., Morteza, H. \& Enayat, R., 2015. The Effect of various levels of dietary protein and methionine on the laying hens' performance and egg characteristics in late laying cycle. Res. Anim. Prod. 5, 13-25.

Bellaver, C. \& Scheuermann, G., 2004. Aplicação dos ácidos orgânicos na produção de aves de corte. In: Conferência AveSui, 1-16, Florianópolis, Brasil.

Belyavin, C.G., Boorman, K.N. \& Volynchook, J., 1987. Egg quality in individual birds. In: R.G. Wells \& C.G. Belyavan (eds). Egg quality current problems and recent advances. Butterworths, London. Pp. 105-122.

Carvalho, L.S.S. \& Fernandes, E.A., 2013. Formação e qualidade da casca de ovos de reprodutoras e poedeiras $\begin{array}{lllll}\text { comerciais. } & \text { Rev. } & \text { Ved. } & \text { 35-44. }\end{array}$ http://www.journals.ufrpe.br/index.php/medicinaveterinaria/article/download/604/483

Chamba, F., Puyalto, M., Ortiz, A., Torrealba, H., Mallo, J.J. \& Riboty, R., 2014. Effect of partially protected sodium butyrate on performance, digestive organs, intestinal villi and $E$. coli development in broilers chickens. Int. J. Poult. Sci. 13, 390-396. http://dx.doi.org/10.3923/ijps.2014.390.396

Feng, J., Zhang, H J., Wu, S G., Qi, G H. \& Wang, J., 2020. Uterine transcriptome analysis reveals mechanism underlying the ultrastructure differences of eggshell in young and aged laying hens. BMC Genomics (in press). https://dx.doi.org/10.21203/rs.3.rs-26128/v1

Herrera, I.S., Hernández, E.P., Ramírez, E.S., Martínez, B.F., Espinoza, J.H., Vega, J.L.L. \& González, E.Á., 2009. Effect of sodium butyrate on diets for laying hens on the productive performance, egg quality and intestinal villi. Vet Méx. 40, 397-403. https://www.medigraphic.com/pdfs/vetmex/vm-2009/vm094f.pdf

Khong, C., Sen, S., Lee, S., Choi, Y., Kim, K.Y., Ingale, S., Kwon, I.K. \& Chae, B.J., 2014. Effect of sodium butyrate supplementation on performance, egg quality and bacterial load in the excreta of laying hens. J. Anim. Res. 4, 141-153. https://dx.doi.org/10.5958/2277-940X.2014.00499.9

Moquet, P.C.A., Onrust, L., Van Immerseel, F., Ducatelle, R., Hendriks, W.H. \& Kwakkel, R.P., 2016. Importance of release location on the mode of action of butyrate derivatives in the avian gastrointestinal tract. World's Poult. Sci. J. 72, 61-80. https://doi.org/10.1017/S004393391500269X

Partanen, K.H. \& Mroz, Z., 1999. Organic acids for performance enhancement in pig diets. Nutr. Res. Rev. 12, 117-145. https://doi.org/10.1079/095442299108728884

Qiu, J.L., Zhou, Q., Zhu, J.M., Lu, X.T., Liu, B., Yu, D.Y., Lin, G., Ao, T. \& Xu, J.M., 2020.Organic trace minerals improve eggshell quality by improving the eggshell ultrastructure of laying hens during the late laying period. Poult. Sci. 99, 1483-1490. https://doi.org/10.1016/j.psj.2019.11.006

Rahman, M.S., Howlider, M.A.R., Mahiuddin, M. \& Rahman, M.M., 2008. Effect of supplementation of organic acids on laying performance, body fatness and egg quality of hens. Bangladesh J. Anim. Sci. 37, 74-81. https://doi.org/10.3329/bjas.v37i2.9884

Rostagno, H.S., Albino, L.F.T., Donzele, J.L., Gomes, P.C., Oliveira, R.F., Lopes, D.C., Ferreira, A.S., Barreto, S.L.T. \& Euclides, R.F., 2011. Tabelas brasileiras para aves e suínos: composição de alimentos e exigências nutricionais. Editora da Universidade Federal de Viçosa, Minas Gerais, Brazil.

Sakomura, N.K., Silva, J.H.V., Costa, F.G.P., Fernandes, J.B.K. \& Hauschild, L., 2014. Nutrição de não ruminantes. Editora da Fundação de Apoio a Pesquisa, Ensino e Extensão, São Paulo, Brazil.

Santos, L.M., 2013. Digestibilidade de nutrientes e desempenho de codornas japonesas suplementadas com ácidos orgânicos após pico de postura. Tese (DSc.) Universidade Federal de Lavras, Minas Gerais, Brazil.

Sengor, E., Yardimci, M., Cetingul, S., Bayram, I., Sahin, H. \& Dogan, I., 2007. Effects of short chain fatty acid (SCFA) supplementation on performance and egg characteristics of old breeder hens. S. Afr. J. Anim. Sci. 37, 158-163. https://www.ajol.info/index.php/sajas/article/view/4086 
Sobczak, A. \& Kozlowski, K., 2016. Effect of dietary supplementation with butyric acid or sodium butyrate on egg production and physiological parameters in laying hens. European Poultry Science, 80, 1-14.

Soltan, M.A., 2008. Effect of dietary organic acid supplementation on egg production, egg quality and some blood serum parameters in laying hens. Int. J. Poult. Sci. 7, 613-621. http://dx.doi.org/10.3923/ijps.2008.613.621

Van Immerseel, F., Fievez, V., Buck, J., Pasmans, F., Martel, A., Haesebrouck, F. \& Ducatelle, R., 2004. Microencapsulated short-chain fatty acids in feed modify colonization and invasion early after infection with Salmonella enteritidis in young chickens. Poult. Sci. 83, 69-74. https://doi.org/10.1093/ps/83.1.69

Wang, A., Wang, Y., Di Liao, X., Wu, Y., Liang, J. B., Laudadio, V. \& Tufarelli, V., 2016 Sodium butyrate mitigates in vitro ammonia generation in cecal content of laying hens. Environ. Sci. Pollut. Res. Int. 23, 16272--16279. https://doi.org/10.1007/s11356-016-6777-z

Wu, W., Xiao, Z., An, W., Dong, Y. \& Zhang, B., 2018. Dietary sodium butyrate improves intestinal development and function by modulating the microbial community in broilers. PLOS ONE 13, 1-21. https://doi.org/10.1371/journal.pone.0197762

Zhang, W.H., Jiang, Y., Zhu, Q.F., Gao, F., Dai, S.F., Chen, J. \& Zhou, G. H., 2011. Sodium butyrate maintains growth performance by regulating the immune response in broiler chickens. Br. Poult. Sci. 52, 292-301. https://doi.org/10.1080/00071668.2011.578121

Zhang, Y., Ma, W., Zhang, Z. Liu, F., Wang, J., Yin, Y. \& Wang, Z., 2019. Effects of Enterococcus faecalis on egg production, egg quality and caecal microbiota of hens during the late laying period. Arch. Anim. Nutr. 73, 208-221. https://doi.org/10.1080/1745039x.2019.1591128 